\title{
Patent lisans sözleşmelerinde dikkat edilmesi gereken hususlar
}

\section{Matters that need to be considered in a patent license agreement}

\author{
Tuğba Akdemir Kamalı1, Levent Kamalı \\ ${ }^{1} Y a s ̧ a r$ Üniversitesi Hukuk Fakültesi, Medeni Hukuk Ana Bilim Dalı, İzmir \\ ${ }^{2}$ Izmir Barosu, İzmir
}

\begin{abstract}
Bu çalışmada, patent kavramının hukuki tanımı yapıldıktan sonra 6769 sayılı Sınai Mülkiyet Kanunu çerçevesinde patentlenebilirlik şartları ve patent korumasının kapsamı ele alınmıştır. Daha sonra üniversitelerin patent geliştirme sürecine etkisi değerlendirilmiş, Dünyada ve Türkiye'de akademik bilgi üretiminin patent başvuruları yoluyla teknoloji ve sanayiye aktarılmasını teşvik edici ve kolaylaştırıcı yasal düzenlemelerden bahsedilmiştir. Bu noktada, tıbbi cihaz ve aletler sektörüne spesifik olarak değinilmiştir. Son olarak, patent lisans sözleşmelerine yönelik 6769 sayılı Sınai Mülkiyet Kanunu'nda getirilen düzenlemeler, lisans sözleşmelerinde Kanun ile tarafların serbest iradelerine bırakılan özel düzenleme alanları, özellikle lisans bedelinin nispi olarak belirlendiği sözleşmelerde sıkça rastlanan uyuşmazlıklar ve çözüm yolları irdelenmiştir.
\end{abstract}

Anahtar sözcülkler: patent; yenilik; buluş basamağı; Bayh-Dole yasası; lisans sözleşmesi ; inhisari lisans; inhisari olmayan lisans

\section{PATENT KAVRAMI}

\section{Patent Nedir?}

Patent, bir buluşun topluma açıklanması karşılı̆̆ında, sahibine buluşun kendi izni olmadan üçüncü kişiler tarafından kullanımını, üretimini, satışını ve ithalini belli bir süreyle engelleme imkânı tanıyan tekel hakkıdır. ${ }^{[1]}$ Bu hakkın kullanılabileceğini gösteren belgeye ise patent belgesi denir. Patent; marka, coğrafi işaret, tasarım ve faydalı model ile birlikte sınaî mülkiyet hakkı kapsamında yer almaktadır.

Günümüzde şirketlerin toplam varlıkları içerisinde fikri sermayenin (patentler, markalar, tasarımlar) payı \%80 seviyesine ulaşmıştır. Örneğin, ABD'de S\&P 500 şirketlerinin toplam değerinin \%80'i maddi olmayan varlıklardan oluşmaktadır. 2018 yılında tarihte ilk kez küresel maddi olmayan varlıkların değeri 50 trilyon ABD dolarını geçmiştir. ${ }^{[2]} \mathrm{Bu}$, dünya ekonomisinin yarıdan fazlasının fikri sermayeden oluştuğu anlamına
In this study after a brief look to the conditions of patentability under the scope of Industrial Property Law No. 6769 , the effect of the patent development process of the universities, promotion of academic knowledge production in the world and Turkey through the patent application, transfer of technology and industry agent and facilitator mainly the medical device and instruments sector. Writers try to evaluate and determine the disputes and solutions that are frequently encountered in licensing contracts where the license fee is determined in proportion and also the special regulation areas, which are left to the free will of the parties by the Industrial Property Law (Law Numbered 6769).

Key words: patent; innovation; inventive step; Bayhe-Dole act; licensing contracts; exclusive license; nonexclusive license

gelmektedir. Patent, günümüzde, sadece teknik anlamda bir buluşun yasal çerçevede korunmasını sağlamak ve buluş sahibinin hakkını ispatlamak üzere yetkili mercilerce verilen belgenin ötesine geçmiş ve teknolojinin para birimi halini almıştır. ${ }^{3]}$

Dünya genelinde, toplam teknik bilginin yaklaşık \%80'ine karşılık gelen 100 milyondan fazla patent bulunmaktadır ve bu patentlenmiş teknik bilgi hazinesi ücretsiz olarak herkesin erişimine açıktır. ${ }^{[2]}$ Dolayısıyla patent, gerçek ve tüzel kişiler tarafından geliştirilen buluşlara kurumsal veya bireysel koruma sağlamanın yanında, buluşun aleniyet kazanması sayesinde fikri ve maddi kaynakların bilinen bir şeyi tekrar bulmaya harcanmasını önleyici bir işlev de görmektedir.

Patent başvurusu veya patent, üçüncü kişilere devir edilebilmekte, miras sözleşmesine konu edilebilmekte ve kullanma hakkı lisans sözleşmesi ile üçüncü kişilere verilebilmektedir.

- İletişim adresi: Öğr. Gör. Tuğba Akdemir Kamalı, Yaşar Üniversitesi Hukuk Fakültesi, Medeni Hukuk Ana Bilim Dalı, İzmir Tel: 0555 - 3078528 e-posta: tugba.kamali@yasar.edu.tr ORCID iD: 0000-0002-1593-4282

- Geliș tarihi: 19 Kasım 2020 Kabul tarihi: 12 Aralık 2020

Levent Kamalı, ORCID iD: 0000-0001-5469-8158 


\section{Patent Tescilinin Şartları}

6769 sayılı Sınai Mülkiyet Kanunu'nun 82/1'inci maddesi, patentlenebilir buluşlar için üç ölçüt saptamıştır. Bunlar; yenilik, buluş basamağı ve sanayiye uygulanabilirliktir.

\section{Yenilik}

Tekniğin bilinen durumuna dâhil olmayan buluşun yeni olduğu kabul edilir. Tekniğin bilinen durumu ise başvuru tarihinden önce dünyanın herhangi bir yerinde, yazılı veya sözlü tanıtım yoluyla ortaya konulmuş veya kullanım ya da başka herhangi bir biçimde açıklanmış olan toplumca erişilebilir her şeyi kapsar. Dolayısıyla buluşun başvuru tarihinden önce bir konferansta veya yayınlanmış bir makalede açıkça ortaya konmuş ya da buluşa konu ürünün piyasaya sürülmüş olması "yenilik" şartını ortadan kaldırır.

Türk ve Avrupa patent hukukunda "mutlak yenilik" söz konusudur. Zira patent başvurusunun yapıldığı tarihten önce, buluş konusunda sadece Türkiye'de değil, dünyanın herhangi bir yerinde toplumca erişilebilir yazılı veya sözlü tanıtım, kullanım veya bir başka yolla açıklanan bilgilerin tümü yenilik ölçütünü ortadan kaldırmaktadır.

Patent başvurusunun bir yanlışlık sonucunda ilgili merci tarafından erken yayınlanması, üçüncü kişilerin gizlilik anlaşmasıyla korunan bilgileri sözleşmeye ya da aradaki güven ilişkisine aykıı bir biçimde açıklamış olması veya bizzat buluş sahibinin yaptığı açıklamalar, başvuruyu tekniğin bilinen durumuna dâhil eder. Ancak bu gibi durumlarda, Sınai Mülkiyet Kanunu'nun 84'üncü maddesinde bir "âtıfet" süresi (grace period) öngörülmüştür. Buna göre, açıklamanın yapıldığı tarihten itibaren on iki ay içinde patent başvurusunun yapılması halinde, söz konusu açıklamalar buluşa patent verilmesini etkilemeyecektir.

\section{Buluş basamă̆ı}

Patent verilebilirlik şartlarının ikincisi buluşun aşikâr olmamasıdır. Tekniğin bilinen durumu dikkate alındığında, ilgili olduğu teknik alandaki uzmana göre aşikâr olmayan buluşun, buluş basamağı içerdiği kabul edilir.

Aşikâr olma ile teknolojinin normal işleyiş sürecinin ilerisine geçmeyen, sadece tekniğin bilinen durumunu izleyen, diğer bir deyimle teknik alandaki bir uzmandan beklenen bilgi ve yeteneğin ötesinde başka bir özellik gerektirmeyen uygulamalar kastedilmektedir.

Buluş basamağı ölçütü, yenilik ölçütüne göre sübjektif bir değerlendirmedir. Patent sisteminde buluş basamağı ölçütünün daha objektif unsurlar kullanılarak değerlendirilebilmesi için bazı yöntemler geliştirilmiştir. Avrupa patent sisteminde buluş basamağının belirlenmesinde kullanılan yöntem, "problem - çözüm” yaklaşımıdır. Buna göre, en yakın önceki teknik ve çözülen teknik problem belirlenmektedir. Bu belirleme yapıldıktan sonra teknikte uzman kişi, önceki teknikte açıklanan bilgileri kullanarak buluşa ulaşabilir mi, sorusunun yanıtı aranmaktadır. Şayet uzman kişi, önceki tekniği kullanarak başvuru konusu buluşa ulaşamıyorsa buluş basamağının varlığı kabul edilecektir. Önemle hatırlatmak gerekir ki, toplumsal hayata veya teknolojik ilerlemeye çarpıcı katkılar sağlayan buluşlar (örneğin, penisilin) kadar, küçük teknolojik iyileştirmeler veya değişiklikler de buluş basamağı içerebilir ve patent korumasından faydalanabilir. ${ }^{[4]}$

\section{Sanayiye uygulanabilir olma}

Patent verilebilmesinin üçüncü ve son şartı, buluşun sanayide uygulanabilir olmasıdır. Buluş, tarım dâhil sanayinin herhangi bir dalında üretilebilir veya kullanılabilir nitelikteyse, sanayiye uygulanabilir olduğu kabul edilir. Teknik bir problemi çözen ve tekrarlanabilir nitelikte olan buluş sanayiye uygulanabilirlik ölçütünü karşılar. Buna karşılık, sadece bir kere kullanılabilen veya tümüyle kuramsal nitelikte olup pratiğe aktarılamayan buluş sanayiye uygulanabilir değildir.

\section{Patent Korumasının Sınırı}

Patent koruması temel olarak, süre ve başvurunun yapıldığı ülke ile sınırlıdır. 6769 sayılı Sınai Mülkiyet Kanunu'nun 101/1'inci maddesi, “Başvuru tarihinden başlamak üzere, patentin koruma süresi yirmi yıl, faydalı modelin koruma süresi on yıldır. Bu süreler uzatılamaz." hükmüne amirdir. Dolayısı ile yirmi yıllık koruma süresinin hitamında patente konu olan buluş topluma mâl olur.

Öte yandan "ülkesellik ilkesi” gereği her ülke kendi belirlemiş olduğu koşulları sağlamak kaydı ile patent hakkını kendi sınırları içinde korumaktadır. Bir başka ülkede geçerli olan bir patent Türkiye'de tescilli değilse, Türkiye sınırları içinde patent sahibinin başka bir ülkede geçerli patente dayanarak üçüncü kişilere karşı bir hak öne sürmesi mümkün olmayacaktır. Patent sahibinin 6769 sayılı Sınai Mülkiyet Kanunu'nun korumasından faydalanabilmesi için mutlaka Türkiye'de patentini tescil ettirmesi gerekmektedir.

\section{ÜNIVERSITELERIN PATENT BAŞVURU SÜRECINE ETKISI}

\section{Bilimsel Yayın Sayısı - Patent Başvurusu Sayısı}

Türkiye, 1991 - 2011 dönemi akademik yayın sayısında bir sıçrama gerçekleştirmiş ve OECD ülkelerini geride bırakmıştır. 2000 yılında 5,000 olan bilimsel yayın sayısı 2011 yılında yaklaşık \%500 artarak yıllık 


\section{Türk Üniversitelerinde Patent Başvuruları [PAURK}

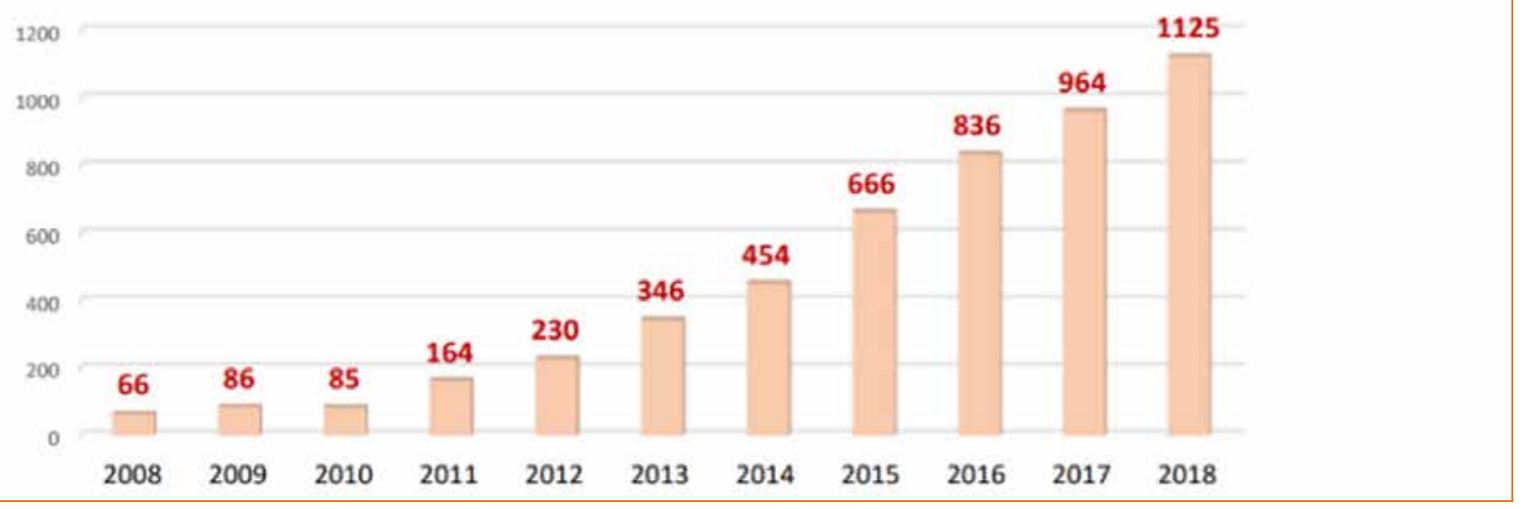

Şekil 1. Türk üniversitelerinde patent başvuruları.. ${ }^{[2]}$

25.000 yayın sayısına ulaşmıştır. Buna karşılık aynı dönemde patent üretimindeki artış hızı, akademik yayın sayısındaki artışın kayda değer oranda altında kalmıştır. Örneğin Güney Kore, 2008 yılında yayınlanan 29,500 bilimsel makaleye karşılık 23.584 patent başvurusu yaparken, Türkiye'nin 18.000 yayına karşıık yaptığı patent başvuru sayısı sadece 85 'tir. Bu istatistik, Türk bilim insanlarınca üretilen fikirlerin çoğunluk kâğıt üstünde kaldığını ve sanayiye aktarılamadığını göstermektedir. ${ }^{[5]}$ Bununla birlikte, Türk üniversitelerinde patent başvuru sayılarının 2011 yılından başlayarak ılımlı bir artış eğiliminde olduğunu söylemek de mümkündür. Türk üniversitelerinin 2010 - 2015 dönemi patent başvuru sayısı toplam 1.945'e ulaşmıştır (Şekil 1). Ancak unutulmamalıdır ki aynı dönemde ülkemizde 204.216 bilimsel yayın yapılmıştır. ${ }^{6]}$ Dolayısıyla bilimsel yayın sayıları ile patent başvuru sayıları arasındaki korelasyon Türkiye'de halen çok zayıftır.

\section{Bayh-Dole Yasası}

Amerikan hukukunda 1980 yılında yürürlüğe giren Bayh-Dole Yasası, kâr amacı gütmeyen organizasyonların veya küçük işletmelerin, federal bir kurumla yaptığı AR-GE sözleşmesi, işbirliği anlaşması veya kurumdan aldığı araştırma desteği ile yaptığı araştırmalarda ortaya çıkan buluşlar üzerinde hak sahibi olmasına izin vermektedir. ABD'de devlet kaynaklı mali destekler ile araştırmaları finanse edilen bazı araştırma kurumlarının, araştırmalar sonucunda ortaya çıkan buluşlar üzerinde hak sahibi olması ve bu buluşları münhasır veya münhasır olmayan lisans sözleşmeleriyle devrederek ticarileştirmesi ve belirli bir gelir elde edebilmesi BayhDole Yasası ile mümkün hale gelmiştir. ${ }^{[7]}$

Bayh-Dole Yasası ile birlikte, özel sektörün akademik araştırmalara ayırdığı destekte de ciddi artış yaşanmıştır. Bu destek, oransal olarak 1970'lerin sonunda \%2,3 iken 2000'li yıllarda \%8'i aşmıştır. Bayh-Dole Yasası'nın yürürlükte olduğu yirmi yıllık sürecin sonun$\mathrm{da}, \mathrm{ABD}$ üniversitelerinin patent sayıları yaklaşık on kat artış gösterirken, bu patentlerden üniversitelerin elde ettiği yıllık lisans geliri ortalama 1 milyar USD seviyesine yükselmiştir. ${ }^{[5]}$

21. yüzyılda üniversitelerin köklü bir değişime uğradığı kuşkusuzdur. Bilim temelli ve tek disiplinli kurumlar olmaktan çıkan üniversiteler, günümüzde multidisipliner araştırma ve girişimcilik gibi üçüncü nesil hedeflere sahiptir. Wissema'nın da belirttiği gibi “Üçüncü Kuşak Üniversiteler yarattıkları bilginin kullanımının ve ticari etkinlik haline getirilmesinin etkin bir biçimde peşinde olurlar ve bunu kendileri için, bilimsel araştırma ve eğitimle eşit önemde üçüncü bir hedef sayarlar”. Ancak bilindiği üzere dünya dördüncü ve hatta beşinci nesil üniversitelere doğru evrilmektedir. Üniversiteler sadece bilgi üreten 
değil bunu aktaran ve ticari değer yaratan bir yapıya dönüşmektedir. Teknolojik yeniliklerin akademinin itici gücüyle sanayiye aktarılması toplumda doğal bir beklenti halindedir. ${ }^{[8]}$

Üçüncü nesil üniversitenin ikinci nesilden en önemli farkı ise araştırmanın ve girişimciliğin eğitime ilave olarak üniversitenin temel amaçları içinde yer almasıdır.

\section{Türkiye'de Üçüncü Nesil Üniversite Hedefine Yönelik Yasal Düzenlemeler}

Sınai Mülkiyet Kanunu'nun Beşinci Kısmında "çalışanların buluşları” düzenlenmiştir. Çalışanın, bir işletme veya kamu idaresinde yükümlü olduğu faaliyeti gereği gerçekleştirdiği ya da büyük ölçüde işletme veya kamu idaresinin deneyim ve çalışmalarına dayanarak, iş ilişkisi sırasında yaptığı buluş, hizmet buluşudur. Hizmet buluşu dışında kalan buluşlar ise Kanun'da serbest buluş olarak tanımlanmaktadır. (6769 sayılı SMK. Madde 113/1-2)

Kanun'un "Yükseköğretim kurumlarında gerçekleştirilen buluşlar” başlıklı 121/1'inci maddesi, “Yükseköğretim kurumlarında yapılan bilimsel çalışmalar veya araştırmalar sonucunda gerçekleştirilen buluşlar için, özel kanun hükümleri ve bu madde kapsamındaki düzenlemeler saklı kalmak kaydıyla, çalışanların buluşlarına ilişkin hükümler uygulanır." hükmüne amirdir. Kanun'un121/8'inci maddesinde ise hizmet buluşundan elde edilecek gelirin yükseköğretim kurumu ile buluşçu çalışan arasındaki paylaşımına asgari bir sınır getirilmiştir. Düzenlemeye göre, buluştan elde edilen gelirin en az üçte biri buluşu yapana verilmek zorundadır. Buluştan elde edilen gelirin yükseköğretim kurumuna ait hissesi, ilgili yükseköğretim kurumu bütçesine özgelir olarak kaydedilir ve başta bilimsel araştırmalar olmak üzere yükseköğretim kurumunun ihtiyaçlarının karşılanması için kullanılır.

Sınai Mülkiyet Kanunu'nda benimsenen bu düzenlemeler, ABD Bayh-Dole Yasası ile paralellikler arz etmektedir. Üniversitelerin kamu kaynaklarını kullanarak ürettikleri patentlere sahip olması, patent hakkının devri veya lisanslanması sonucu elde edilecek gelirin üniversiteye özgelir olarak bırakılması, ayrıca elde edilecek gelirin en az üçte birinin buluşu yapan akademisyenlere verilecek olması, akademide üretilen bilginin sanayi ve teknolojiye aktarımını teşvik edici niteliktedir.

Bunun yanında, Türkiye'de 03.07.2014 tarihinde 6550 sayılı Araştırma Altyapılarının Desteklenmesine Dair Kanun yürürlüğe girmiştir. Kanun'da "araştırma altyapısı", yükseköğretim kurumları bünyesinde, yetişmiş nitelikli insan gücü ile günün modern teknolojilerine dayalı makine-teçhizat, donanım ve yazılımı içinde bulunduran, Ar-Ge faaliyetlerinin yapıldığı ileri araştırma laboratuvarı, tematik araştırma laboratuvarı ile merkezî araştırma laboratuvarı olarak sınıflandırılan birimleri ifade etmektedir.

Gerek 6769 sayılı Sınai Mülkiyet Kanunu'nda yapılan düzenlemeler, gerekse araştırma altyapılarının desteklenmesine yönelik 6550 sayılı Kanun, akademik bilgi üretiminin sanayi ve teknolojiye yönlendirilmesini, böylelikle patent başvuru sayılarının üniversitelerin itici gücüyle arttırılmasını, ezcümle fikri sermayenin ülkemizde güçlendirilmesini amaçlamaktadır.

\section{Tıbbi Cihaz ve Aletler Sektörüne Spesifik Bir Bakış}

Dünya tıbbi cihaz pazarında söz sahibi olan ABD, Japonya ve Almanya, aynı zamanda Ar-Ge çalışmaları harcamalarına göre yüksek yenilik yarışında ön sıralardaki yerlerini almışlardır. Dünya ülkelerinin ArGe harcamalarına ilişkin 2014 yılı tahmini rakamlarına bakıldığında; ABD 465 milyar dolar Ar-Ge harcaması ile ilk sırada, hemen ardından 284 milyar dolar ile Çin ikinci sırada, Ar-Ge harcamalarının gayrisafi yurtiçi hâsıla içindeki en yüksek pay oranına sahip olan Japonya 165 milyar dolar ile üçüncü sırada yer alırken, Türkiye bu listede 11 milyar dolar Ar-Ge harcaması ve 0,9 pay oranı ile 20 . sırada yer almaktadır. ${ }^{[9]}$

Türkiye'de sayısı 1000'e yakın yerel tıbbi cihaz üreticisi ve tedarikçisi bulunmaktadır ve sektörde yer alan bileşenlerin \%70'i ürünlerini ihraç etmektedir. Yerel üreticiler, Türkiye'de yoğun olarak İstanbul, İzmir, Ankara, Samsun ve Konya'da faaliyet göstermektedir. Yerel üreticiler tıbbi cihaz pazarındaki talebin ancak \%15'ini karşılayabilmektedirler. Türkiye pazarında sermayesini kamudan alan sektör bileşeni yoktur; pazar tümüyle özelleşmiş haldedir. Yerel üreticilerin Ar-Ge alanındaki çalışmalarının yetersiz kalması, pazar taleplerinin ithalatla karşılanmasına sebep olmaktadır. ${ }^{[9]}$

Türkiye'deki tıbbi alet üreticileri tarafından yapılan patent ve faydalı model başvurularının büyük çoğunluğu (implantlar, plaklar, vidalar, intramedüller çiviler, eksternal fiksatörler, kalça ve diz protezleri, kelepçeler, vd.) ortopedi ve travmatoloji alanındaki buluşlardan oluşmaktadır. Anılan patent başvurularına yönelik Türk Patent ve Marka Kurumu nezdinde yaptığımız dosya araştırmasında, başvurularda "buluş̧̧u" olarak beyan edilen kişilerin yarıdan fazlasının ortopedi ve travmatoloji uzmanı hekimler olduğu görülmüştür. Ancak buluş sahibi olmalarına karşın, patent başvurularının kayda değer kısmında uzman hekimler "başvurucu" olarak yer almamaktadır. Bir kısım patent başvurusunda ise buluşçu uzman 
hekimler ile yerel üreticilerin ortak başvurucu oldukları görülmektedir.

Özellikle ortopedi ve travmatoloji alanındaki cerrahi ve tedavinin, malzeme bilimi (metalürji) ve biyomedikal mühendislik ile çok yakın bir ilişkisi vardır. ${ }^{[5]}$ Bu ilişki, ortopedi ve travmatoloji alanındaki ürünlere yönelik patent üretiminde disiplinler arası işbirliğini zorunlu kılmaktadır. Yükseköğretim kurumları bünyesinde multidisipliner araştırma altyapılarının henüz yeterli seviyede olmaması, mesleki ve akademik çıktılarını sanayiye aktarma aşamasında hekimlerimizi yerel üreticilere ait tesisleri kullanmaya ve üreticilerin teknik personeli ile çalışmaya yönlendirmektedir. İşte bu noktada, buluşçu hekimlerimizin patent geliştirme sürecinde işbirliği yaptıkları yerel üreticiler karşısında yasal haklarını koruyabilmelerinde ve özellikle buluşun ticarileşmesi sonucu elde edilecek gelirde hak sahibi olabilmelerinde patent lisans sözleşmeleri büyük önem arz etmektedir.

\section{PATENT LISANS SÖZLEŞMESi}

\section{Amaç}

Patent lisans sözleşmesinde, patent hakkı sahibine ait gayri maddi hak üzerindeki kullanım hakkının bir başkasına bırakılması amaç edinilmektedir. Dikkat edilirse burada mülkiyet hakkının üçüncü kişilere devri amacı yoktur. Patent lisans sözleşmesi, sadece patent kullanım hakkının devrine ilişkin bir sözleşmedir. Bir diğer ifadeyle, patent hakkının devrinde, hak sahibi, patent üzerindeki tüm hak ve yetkilerini üçüncü kişiye devretmekteyken, lisans sözleşmelerinde hak sahibi patent üzerindeki haklarını korumaya devam etmektedir. ${ }^{[3]}$

\section{Patent Lisans Sözleşmesinin Şekli}

6769 sayılı Sınai Mülkiyet Kanunu'nun 148/4'üncü maddesinde, sınai mülkiyet hakkına ilişkin hukuki işlemlerin yazılı şekle tabi olduğu ifade edilmektedir. Türk hukukunda yazılı olmayan lisans sözleşmeleri geçersizdir. Öte yandan, patent lisans sözleşmelerinin noterde onaylanma zorunluluğu bulunmamaktadır. Kanun, noter onayını sadece sınai mülkiyet hakkının devrine ilişkin sözleşmelerde bir geçerlilik şartı olarak düzenlemiştir. Lisans sözleşmelerinin elektronik ortamda, yasal kimlik doğrulama sistemi (elektronik imza) kullanılmak suretiyle düzenlenmesi mümkündür. Patent hakkının birden çok kimseye ait olması durumunda ise patent hakkına ilişkin tasarruf yetkisi hak sahiplerinin tamamına ait olacağından, lisans sözleşmesinin bunların tamamı tarafından yapılması gerekmektedir.

\section{Lisans Sözleşmesinin İskeleti}

Bir lisans sözleşmesinin iskeleti şu şekildedir ${ }^{[10]}$ :

- Tarafların belirtilmesi

- Giriş̧

- Tanımlar

- Devredilen lisans

- Zararın tazmin edilmesi

- Tarafların yükümlülükleri

- Sözleşmenin süresi ve feshi

- Uyuşmazlık çözümü

- Diğer genel hükümler

\section{Lisans Kapsamının Belirlenmesi}

6769 sayılı Sınai Mülkiyet Kanunu'nun 125/4'üncü maddesi, "Sözleşmede aksi kararlaştırılmamışsa sözleşmeye dayalı olarak lisans alan kişi, patentin koruma süresi boyunca patent konusu buluşun kullanılmasına ilişkin her türlü tasarrufta bulunabilir." hükmüne amirdir. İşbu madde hükmü, lisans sözleşmesinde süre, bölge veya tasarrufa ilişkin sınırlayıcı hükümlerin yer almasına imkân tanımaktadır. Örneğin lisans veren, patent koruma süresi yirmi yıl olduğu halde lisans sözleşmesini on yıl veya dilerse daha az bir süreyle sınırlandırabilir. Yine lisans sözleşmesinde, patent kullanım hakkı dar bir bölge, örneğin bir ya da birkaç il ile sınırlı tutulabilir. Öte yandan lisans sözleşmesinde, patent konusu buluşun üretim hakları sözleşme dışı tutularak, lisans alana sadece buluşun satış ya da ithalat hakkı verilebilir. Kısacası, patent lisans sözleşmesinde, patent hakkı sahibine ait gayri maddi hak üzerindeki kullanım hakkının bölünerek bir başkasına bırakılması mümkündür. Ancak bunun için sözleşmede tereddüde mahal vermeyecek şekilde açık ve anlaşılır düzenlemeler yapmak gerekmektedir. Aksi halde lisans alan kişi, patent koruma süresinin sonuna kadar bir bütün olarak patent konusu buluşun kullanılmasına ilişkin her türlü tasarrufta bulunabilecektir.

\section{İnhisari Lisans - İnhisari Olmayan Lisans}

6769 sayılı Sınai Mülkiyet Kanunu'nun 125/2'nci maddesi, "Lisans, inhisari lisans veya inhisari olmayan lisans şeklinde verilebilir. Sözleşmede aksi kararlaştırılmamışsa lisans, inhisari değildir. Inhisari olmayan lisans sözleşmelerinde lisans veren patent konusu buluşu kendi kullanabileceği gibi, üçüncü kişilere aynı buluşa ilişkin başka lisanslar da verebilir. Inhisari lisans söz konusu olduğu zaman, lisans veren başkasına lisans veremez ve hakkını açıkça saklı tutmadıkça, kendisi de patent konusu buluşu kullanamaz." hükmüne amirdir. 
Kanun metninden açıç̧a anlaşılacağı üzere, inhisari lisans sözleşmesinde, patent konusu buluşun kullanım hakkı münhasıran lisans alana bırakılmaktadır. Ancak bu halde dâhi, lisans veren, şayet lisans sözleşmesinde hakkını açıkça saklı tutmuş ise patent konusu buluşu bizzat kullanabilecektir. İnhisari lisans sözleşmesinde, lisans verenin lisans alan dışındaki üçüncü kişilere lisans veremeyeceği ve hakkını sözleşmede açıkça saklı tutmamışsa lisans verenin dâhi patenti kullanamayacağı hüküm altına alınmaktadır. ${ }^{[11]}$

Öte yandan lisans veren, patent konusu buluşun kullanım hakkını inhisari olmayan lisans sözleşmeleriyle birden fazla kişiye verebilir ve sözleşmede hakkını sakI tutup tutmadığına bakılmaksızın kendisi de buluşu kullanabilir. Bir başka ifadeyle, inhisari olmayan (basit) lisans sözleşmelerinde, lisans veren, lisans alana patent hakkının kullanımına ilişkin yetki verirken, daha sonra başkalarına aynı içerikte ve aynı coğrafi alanda lisans verme hakkını saklı tutmaktadır.

\section{Lisans Alanın Devir Yasağı}

6769 sayılı Sınai Mülkiyet Kanunu'nun 125/3'üncü maddesi, "Sözleşmede aksi kararlaştııılmamışsa lisans sahipleri, lisanstan doğan haklarını üçüncü kişilere devredemez veya alt lisans veremez." hükmüne amirdir. Ancak taraflar, lisans alanın sözleşmeden doğan haklarını üçüncü kişilere devredebileceğini veya alt lisans verebileceğini her zaman kararlaştırabilirler. Her hâlükârda lisans alanın alt lisans verebilmesinin lisans sözleşmesinde açıkça düzenlenmiş olması gerekmektedir; aksi takdirde lisans alanın alt lisans verebilmesinden söz etme imkânı olmayacaktır.

Lisans sahibi, özellikle ticari sırları bakımından alt lisanslama konusunda çok dikkatli olmalıdır. Zira alt lisanslama ilişkisinde bir tarafın fikri mülkiyet hakkına ilişkin doğrudan kontrol kabiliyeti ortadan kalkmaktadır. Eğer ki alt lisanslama tesis edilirse, sözleşmede genel bir uygulama olarak lisans sahibine herhangi bir alt lisanslama sözleşmesinin hüküm ve şartlarını onaylama yetkisini veren hükümler bulunur veya en azından alt lisanslama sözleşmesinin, lisanslama sözleşmesinde kararlaştıılan hükümlerle aynı şekilde kaleme alınacağı belirtilir. ${ }^{[10]}$

\section{Sicile Kayıt}

6769 sayılı Sınai Mülkiyet Kanunu'nun 106/2'nci maddesinde, lisans sözleşmelerinin iyiniyetli üçüncü kişilere karşı sicile kayıt tarihinden itibaren hüküm doğuracağı düzenlenmiştir. Hemen belirtelim, patent lisans sözleşmesinin sicile tescil edilmemesi sözleşmenin geçerliliğini etkilemez; ancak lisans sözleşmesinin iyiniyetli üçüncü kişilere karşı ileri sürülebilmesi için sicile kayıt zorunludur.
Patent lisans sözleşmesinin sicile tescili için Türk Patent ve Marka Kurumu'na aşağıdaki belgelerle başvurulması gerekmektedir:

- Dilekçe

- Taraflarca imzalı ve imzaları onaylı lisans sözleşmesi

- Patent belgesi aslı veya belge aslı sunulamıyorsa onaylı patent belgesi düzenlenmesine ilişkin talep

- Gerekli harcın ve ücret tarifesinde belirtilen ücretin yatırıldığını gösterir belge.

\section{Lisans Bedeli}

Her sözleşmede olduğu gibi patent lisans sözleşmelerinde de çözüme kavuşturulması gereken en önemli konu sözleşme bedelinin tayinidir. Lisans bedeli, lisans alan tarafından lisan verene ödenecek sabit (götürü) bir bedel olabileceği gibi; parça başı, ciro veya kâr üzerinden belirlenecek nispi bir bedelin ödenmesi de taraflar arasında kararlaştırılabilir. Hatta lisans sözleşmelerinde, sabit ve nispi bedelin birlikte uygulandığı karma bir ödeme yöntemi de belirlenebilir.

\section{Sabit (götürü) lisans bedeli}

Patent lisans sözleşmelerinde sabit lisans bedelinin belirlendiği hallerde, taraflar sözleşme imzalanmadan önce ya da en geç sözleşme imzalanırken lisans verilmesi karşılığında ödenecek olan lisans bedelini kesin biçimde ve götürü bir para miktarı üzerinden kararlaştırmaktadırlar. ${ }^{[3]}$ Üzerinde anlaşmaya varılan bu bedel, tek bir seferde lisans verene ödenebileceği gibi, taksitler halinde de ifa edilebilir. Dönemsel ödemelerin kararlaştırıldığı hallerde ödenecek her bir meblağın diğeriyle eşit miktarda olması gibi bir zorunluluk kural olarak yoktur. Bu konuda, tarafların sözleşmede diledikleri gibi uzlaşmaya varmaları mümkündür.

\section{Nispi lisans bedeli}

Patent lisans sözleşmelerinde, lisansa konu hakkın karşılı̆̆ı olarak ödenecek bedelin, parça başına, ciroya katılım ya da kâra katılım yöntemiyle belirlenmesi mümkündür. Bu hallerde lisans verenin elde edeceği lisans bedeli, lisans konusu patentin ve tabi ki lisans alanın elde edeceği ticari başarıya göre değişecektir. Buradaki önemli husus, lisans alanın lisans konusu ürüne yönelik üretim adedi, satış adedi, maliyet ve satış fiyatları gibi ticari bilgilerini ve bu bilgilerin yer aldığı ticari defterlerini lisans verenin denetimine açık tutmasıdır. Nispi lisans bedeli yönteminin belki de en kritik ve uyuşmazlığa en müsait tarafı işbu ticari şeffaflığın sağlanıp sağlanamaması noktasında toplanmaktadır. Bu sebeple, lisans alanın ticari defter ve kayıtlarını belli usuller çerçevesinde ve öğrenilecek ticari sırların gizli 
tutulması kaydıyla lisans verenin denetimine açacağına yönelik hükümlerin lisans sözleşmesinde düzenlenmesi faydalı olacaktır.

Parça başına bedel: Patent lisans sözleşmelerinde taraflar, lisans konusu kullanılarak üretilen veya satılan her bir parça mal için sabit bir tutarın ödenmesini kararlaştırabilecekleri gibi, her bir parça malın üretimi veya satımı üzerinden belirli bir yüzde oranı ile lisans bedelini kararlaştırabilirler. ${ }^{[3]}$ Patent lisans sözleşmelerinde, parça başına belirli bir yüzdenin, parça başına sabit bir miktara oranla daha çok tercih edilmesindeki ana sebep, lisans verenin, zaman içinde gerçekleşebilecek fiyat artışlarından yararlanma ve paranın değerindeki değişikliklerden etkilenmeme arzusudur.

Ciroya katılım yöntemi: Patent lisans sözleşmelerinde, lisans bedelinin ciroya katılım yöntemi ile belirlendiği hallerde, lisans alan, lisans sözleşmesi uyarınca ödemesi gereken lisans bedelini, satış cirosuna göre lisans verene ifa etmektedir. Bu yöntemde lisans alan, sözleşmeye konu hakkı kullanmak suretiyle elde ettiği ciroya, sözleşmede kararlaştırılan oranı uygulamakta ve bu suretle lisans verene ödemesi gereken tutar belirlenmektedir. Tabi burada lisans bedelinin aylık, altı aylık veya yıllık ciro üzerinden mi belirleneceği sözleşmede açıkça belirlenmelidir.

Kâra katılım yöntemi: Patent lisans sözleşmelerinde, lisans bedelinin nispi şekilde belirlendiği bir diğer yöntem kâra katılım yöntemidir. Söz konusu yöntemde lisans alan, sözleşmeye konu hakkı kullanmak suretiyle elde ettiği kâr üzerinden, yine sözleşmede daha önceden belirlenmiş olan oranı uygulamak suretiyle hesaplanacak lisans bedelini lisans verene ödemektedir. Bu yöntemin kritik noktası kârın hesaplanmasıdır. Ciro, bir işletmenin ürettiği net satışlar iken, kâr o işletmenin net satışlar üzerinden tüm giderler düşüldükten sonra kalan kazancıdır. Dolayısıyla kârın hesaplanması, hem cironun hem de gider kalemlerinin bilinmesine bağlıdır. Bu nedenle, kâra katılım yönteminde lisans alanın lisans verene en üst seviyede ticari şeffaflık sağlaması, buna karşılık lisans verenin de öğrendiği ticari sırları saklaması gerekmektedir.

\section{Karma lisans bedeli}

Karma lisans bedelinin belirlendiği ve uygulandığı hallerde, lisans verenin hem sabit bedel hem de nispi bedel belirlenmesi yöntemlerinin avantajlı yanlarından yararlanması mümkündür. Lisans veren, sözleşmede baştan sabit bir şekilde kararlaştırılan bedeli alması ile lisans konusunun muhtemel başarısızlıklarına karşı kendisini korumuş olacaktır. Aynı zamanda, lisans konusu patentin muhtemel başarısı halinde de üretim ve kullanımdan ayrıca nispi bedel yöntemi ile yarar sağlayacaktır. ${ }^{[12]}$

\section{SONUÇ}

Türk bilim insanlarınca üretilen buluşların patentlenerek sanayiye aktarılması ve böylece fikri sermayenin güçlendirilmesi stratejik bir hedeftir. Son beş yıl içinde gerek 6769 sayılı Sınai Mülkiyet Kanunu'nda yapılan düzenlemeler, gerekse Türkiye'de Ar-Ge altyapılarının kurulması ve desteklenmesine yönelik çıkartılan 6550 sayılı Kanun, özellikle akademik bilgi üretiminin sanayi ve teknolojiye yönlendirilmesi hedefine dönük hukuki bir zemin oluşturmaktadır. Ancak bu hedefe yönelik yükseköğretim kurumları bünyesinde fiziki Ar-Ge altyapılarının gelişmesi ve güçlenmesi zaman alacaktır.

Tıbbi cihaz ve aletler sektörü özelinde yerel üreticilerin Türkiye pazarındaki talebi karşılama oranı \%15 ile arzu edilen seviyenin oldukça altındadır. Yerel üreticilerin Ar-Ge harcamalarına ayırdıkları pay sınırlıdır. Bu, yüksek teknoloji içeren ürünlerin üretilmesini de sınırlandırmaktadır. Sektörün ürün çeşitliliği, ağırıklı olarak ortopedi ve travmatoloji alanında cerrahi uygulamada ve tedavide kullanılan tıbbi ürünlerden oluşmaktadır. Mevcut koşullarda, yerel üreticiler ile ortopedi ve travmatoloji uzmanı hekimlerimizin patent geliştirme süreçlerinde sıkça işbirliğine gittiği görülmektedir. Bu işbirliği sonucunda patentlenen buluşların üretimi, dağıtımı ve satışı hemen her zaman yerel üretici tarafından üstlenilmekte, dolayısıyla patentin kullanım hakkı zımnen üreticiye bırakılmış olmaktadır. İşte bu noktada, buluşçu hekimlerimizin ticarileşen buluşun elde edeceği başarı üzerinde hak sahibi olabilmeleri patent lisans sözleşmeleri ile mümkün hale gelmektedir.

Patent lisans sözleşmesinde, mülkiyeti patent hakkı sahibinde kalmak üzere, patentin kullanım hakkının bir başkasına bırakılması amaç edinilmektedir. Bu bakımdan lisans sözleşmeleri, hasılat kirası sözleşmeleri ile paralellikler arz etmektedir.

6769 sayılı Sınai Mülkiyet Kanunu'nda lisans sözleşmelerinin yazılı şekilde yapılması geçerlilik şartı olarak düzenlenmiştir. Lisans veren, sözleşmede açıkça belirtilmesi koşuluyla lisans alana vereceği patent kullanım hakkını süre, bölge veya tasarruf kabiliyeti yönlerinden sınırlandırabilir. Patent lisans sözleşmelerinde açıkça belirtilmedikçe, lisans alanın kullanım hakkı inhisari olmayacaktır. İnhisari lisans sözleşmelerinde ise lisans veren, sözleşme sona ermeden başkasına lisans veremeyecek ve hakkını sözleşmede açıç̧a saklı tutmadıkça, kendisi de patent konusu buluşu kullanamayacaktır. Diğer yandan lisans alan, sözleşmede açıkça kararlaştırılmadıkça alt lisan veremez. Görüldüğüu üzere, taraflar arasındaki hukuki ilişkinin özelleştirilmesi patent lisans sözleşmesinin detaylı olarak ve titizlikle düzenlenmesini gerektirmektedir. 
Uygulamada lisans sözleşmelerinden kaynaklı uyuşmazlıklar, çoğunluk lisans bedelinin tespitine ve ödenmesine ilişkin anlaşmazlıklardan kaynaklanmaktadır. Özellikle lisans alanın lisans verene parça başı, ciro veya kâr üzerinden nispi lisans bedeli ödemeyi taahhüt ettiği sözleşmelerde, lisans verene ödenecek lisans bedelinin hesaplanması bakımında sorunlar ortaya çıkmaktadır. Nispi lisans bedelinin tespitinde ortaya çıkabilecek muhtemel uyuşmazlıkların sözleşme ile sınırlandırılması elbette mümkündür. Bunun için lisans alanın buluşa ilişkin üretim, satış, fiyat, maliyet gibi lisans bedelinin hesaplanmasında zorunlu olan ticari kayıt ve bilgileri belirli dönemlerde lisans verenin gözetim ve denetimine açık tutulması büyük önem arz etmektedir. Bu maksatla lisans alanın dönemsel olarak lisans verene belgeye dayalı raporlama yapacağı sözleşmede hüküm altına alınabilir. Süresinde yapılmayan, gerçeğe aykırı veya eksik yapılan raporlamalarda lisans alanın lisans verene yoksun kalınan kâr ile birlikte uygun bir cezai tazminat ödeyeceği de kararlaştırılabilir. Her hâlükârda, sözleşme tarafları arasında şeffaflığın arttırılması muhtemel uyuşmazlıkları asgari seviyede tutacaktır.

\section{KAYNAKLAR}

1. Öztürk, Ö. Türk Hukukunda Patent Verilebilirlik Şartları, 1. Baskı. Seçkin Yayınevi; 2008, s.3.

2. Asan, H. Türkiye Üniversitelerinde Patent Bilgisinin Kullanımı ve Yeni Bir İşbirliği Projesi (Sözlü Sunum). Manisa Celal Bayar Üniversitesi, 31.10.2019, Manisa, s. 4, 5. https://www.mcbu. edu.tr/FileArchive/File-2305-MQWN011120191630.pdf
3. Durak SO. Patent Lisans Sözleşmesi, İstanbul Üniversitesi Sosyal Bilimler Enstitüsü Özel Hukuk Ana Bilim Dalı Yüksek Lisans Tezi (yayımlanmamış tez). İstanbul: 2007. s.5

4. Gökovalı Ü, Bozkurt K. Fikri ve Sınaî Mülkiyet Hakkı (FSMH) Olarak Patentler: Dünya ve Türkiye Açısından Tarihsel Bir Bakış. Muğla Üniversitesi Sosyal Bilimler Enstitüsü Derg (ILKKE) 2006;17:135-46. https://dergipark.org.tr/tr/ download/article-file/217306

5. Havıtçıoğlu H. Yaratıcı Üniversite ve Bilgi Toplumu. İzmir: Gülermat Matbaacılık; 2016. s.197.

6. Dünya, Ülkeler ve Gruplar Bilimsel Yayın Sayısı (20102015). https://cabim.ulakbim.gov.tr/wp-content/uploads/ sites/4/2016/07/D\%c3\%bcnya-\%c3\%9clkeler-ve-GruplarBilimsel-Yay\%c4\%b1n-Say\%c4\%b1s\%c4\%b1-2010-2015.pdf

7. Merhacı ÖS. Amerika Birleşik Devletleri Bayh-Dole Yasası ve Türk Hukukunda Öğretim Elemanlarının Buluşlarına iliş̧kin Bir Değerlendirme. AÜHFD 2015;64:405-34. https:// dergipark.org.tr/tr/download/article-file/622517

8. Ernek Alan GA. Türkiye'de Yeni Nesil Üniversiteler. Maltepe Üniversitesi Illetişim Fakültesi Derg 2016;3:105-18. https:// dergipark.org.tr/en/download/article-file/304427

9. Arık Ö, Illeri Y, Kaya B. Sağlık Hizmetlerinde Tıbbi Cihaz Sektörü. Hacettepe Sağlık Idaresi Derg 2016;19:187-202. https://dergipark.org.tr/tr/download/article-file/225561

10. Cameron DM, Borenstein R. Fikri Mülkiyet Sözleşmesinin Anahtar Noktaları. İçinde: Memiş T, editör. Fikri Mülkiyet Hukuku Yıllığı 2019, 1. Baskı. (Çeviri: Alper Sargın). Ankara: Yetkin Yayıncilık; 2020. s.43-64.

11. Tekinalp Ü. Fikrî Mülkiyet Hukuku, 5. Baskı. İstanbul: Vedat Kitapçılık; 2012. s.562.

12. Ongan B. Sınai Haklara İlişkin Lisans Sözleşmelerinde Tarafların Hukuki Durumu. Ankara: Seçkin, 2007. s.109. 